\title{
Emil Behring's Medical Culture: From Disinfection to Serotherapy
}

\author{
JONATHAN SIMON*
}

The introduction of the first serum therapies for the treatment of diphtheria and tetanus in the mid-1890s constitutes an important development in the history of medicine. The technique-pioneered by Emil Behring (1854-1917)—involved the injection of bloodserum extracted from animals after they had been rendered immune to the disease in question. In retrospect, it is easy to identify this approach as providing the first effective specific biological-as opposed to chemical-treatment for infectious diseases. Such a retrospective assessment is, however, deceptive on several accounts; first, extracts of animals - usually derived from blood, individual organs or specific glands-abounded in this period and were used in all manner of indications both general and specific, from extract of testicles for male impotence to extract of pancreas for problems of digestion or diabetes. Thus, while it is easy to think of sera as distinct from these other "quack" medicines, because of their efficacy against specific diseases, this was far from clear for doctors at the turn of the nineteenth and twentieth centuries. Second, it is quite natural today to think of the function of such sera in terms of immunology and the harnessing of the specificity of an animal's immune response for curative or even preventive purposes, but treatment using sera was introduced without any clear theoretical vision of how it might work. To see how general the understanding of the serum's action was at the time, we need only recall Behring's famous reflection on the purported value of blood transfusion that concluded the first experimental success with this serum therapy: "Blood is a very special juice". Indeed, all the classic histories of bacteriology and immunology seek, quite legitimately, to place Behring's discovery within the early history of immunology. ${ }^{2}$ In this context, the development of serotherapy in Germany finds its principal role as an assault on Metchnikoff's phagocytic theory, setting the stage for the clash between German humoral and French cellular theories of immunity that is regarded as the discipline's

(C) Jonathan Simon 2007

* Dr Jonathan Simon, LIRDHIST, Université Lyon 1, F-69622 Villeurbanne Cedex; and Institut für Geschichte der Medizin, Charité, Berlin; e-mail: jsimon@univ-lyonl.fr

I would like to thank Volker Hess, Christoph Gradmann, Alex Hüntelmann and the two anonymous reviewers for Medical History for their useful comments. This publication is part of a research project, 'The Industrialization of Experimental Knowledge', directed by Volker Hess, and funded by the Deutsche Forschungsgemeinschaft, HE 2220/4.

\footnotetext{
${ }^{1}$ Behring is here quoting Goethe's Faust: "Blut ist ein ganz besonderer Saft.” Emil Behring and
}

Shibasaburo Kitasato, 'Ueber das Zustandekommen der Diphtherie-Immunität und der Tetanus-Immunität bei Thieren', Deutsch. med. Wochenschr., 1890, 16 (49): pp. 1113-14, on p. 1113. Behring was at this time well aware of the specificity of the anti-bacterial activity of blood, as well as its apparent unpredictability; Emil Behring, and F Nissen, 'Ueber bacterienfeindliche Eigenschaften verschiedener Blutserumarten. Ein Beitrag zur Immunitätsfrage', Zeitschrift für Hygiene, 1890, 8: 412-33, on p. 431.

${ }^{2} \mathrm{~W}$ D Foster, A history of medical bacteriology and immunology, London, Heinemann, 1970, and more recently, and with more contextual sensitivity, Arthur M Silverstein, A history of immunology, San Diego, Academic Press, 1989. 


\section{Jonathan Simon}

founding debate. ${ }^{3}$ Nevertheless, it was not the way in which Behring presented his work that gave rise to serotherapy. Although he did reject the mechanism of phagocytosis, Behring did not project his original research into the future of immunology, but chose instead to present the blood serum in much more familiar terms, as an antiseptic or disinfectant. Why, we might ask, did he make any such reference to disinfection at all in this context? Exploring this idea of disinfection, rather than simply inscribing serotherapy into the early history of immunology, leads us to consider the broader meaning of disinfection in fin-de-siècle Germany as well as the use of disinfectants in micro-biological research in Berlin at this time. This is the direction I follow in this paper by focusing on the role of disinfection and disinfectants in the research career of Emil Behring. This trail leads us from his initial publications on iodoform - an innovative, if controversial disinfectantto the development of serotherapy over a decade later. Overall, the use of disinfection and disinfectants as the organizing principle for presenting this history obliges us to understand the new therapeutic agent (animal-derived serum) less as the first therapeutic triumph of a nascent field of immunology, and more as a practical achievement that depended on a set of skills and reagents drawn from a variety of contexts, including, in particular, German military medicine. Indeed, in this context it is much easier to understand why Behring so readily interpreted his own elaboration of serotherapy, at least initially, in the disinfectant tradition.

In this paper, therefore, I will start by considering the influence of military medicine and Behring's own medical career on his first publications on iodoform. Next, I want to show how his early interest in disinfectants led Behring logically, if not inevitably, into the group of microbiologists that had constituted itself around Robert Koch (1843-1910) in Berlin in the 1880s. The final task is to show how the work that led to the introduction of serotherapy was inscribed in the same tradition of disinfection research that had led Behring to Berlin and his collaboration with Kitasato in the first place. Nevertheless, I end the study here, with the first publications on the principle of serotherapy. Although an interesting story, the development and stabilization of the use of such serum in human medicine by Behring and Erich Wernicke in the early 1890s is beyond the scope of this paper. Finally, while this is essentially the story of a research career within the German empire, I refer to military and industrial influences that informed medical theory and research throughout western Europe and the eastern United States. This is not intended, however, to be a comparative analysis, and the alternative approaches that oriented research outside Germany are only briefly alluded to in order to illustrate the specificity of the German configuration of microbiological research and the prominent place assigned to disinfectants and disinfection in this context.

\section{The Origins of Serotherapy}

The research that led up to the introduction of serotherapy as a treatment for diphtheria and tetanus was shared between two centres for research in microbiology; the Pasteur

\footnotetext{
${ }^{3}$ Written fifty years after the events, Bulloch's history is the first to make use of this debate to mark the transfer from bacteriology to immunology.
}

William Bulloch, The history of bacteriology, London, Oxford University Press, 1938, particularly ch. 11 . 


\section{Emil Behring's Medical Culture}

Institute in Paris and Koch's group in Berlin. Indeed, the standard histories of the crucial discoveries that form the mileposts on the way to the therapy take us regularly back and forth from Prussia to France. While it was Friedrich Löffler (1852-1915) who isolated the bacillus associated with the disease in Berlin in 1882, and at the same time postulated a mode of action involving the production of a toxin, it was Émile Roux (1853-1933) and Alexandre Yersin (1863-1943) in Paris who, in 1888, first reported purifying the toxin responsible for diphtheria's peculiar gravity as a childhood disease. ${ }^{4}$ We return to Berlin for the publication in 1890 by Emil Behring and Shibasaburo Kitasato (1852-1931) of a set of experiments that introduced the possibility of rendering a rabbit immune to the toxin associated with the tetanus bacilli by injecting it with blood serum taken from an animal formerly immunized by other experimental means. ${ }^{5}$ The race was then on to find a safe and practical way to convert this principle into a means for treating diphtheria in humans, an application clearly predicted by Behring in $1890 .^{6}$ Nevertheless, the apparent continuity behind this shuttling to and fro in the history disguises important differences in the approaches adopted either side of the Vosges. ${ }^{7}$ In part, this is a question of difference in the national styles of microbiology. Koch's development of sophisticated in vitro techniques-including innovations in pure cultures-and a focus on specific animaldisease models contrasts with the more empirical approach of Louis Pasteur (1822-95) in which he favoured the passage of pathogens through animal hosts to try to accentuate or later attenuate "viruses" for therapeutic applications. Furthermore, it can be argued that Koch's background as a doctor and his exclusive interest in medical microbiology meant he was at once more focused on human infectious disease but lacked the breadth of microbiological experience that came with Pasteur's interest in the commercial, particularly agricultural, relevance of micro-organisms. ${ }^{8}$ Indeed, as far as paradigms for developing effective treatments are concerned, Andrew Mendelsohn has argued that the advent of serotherapy helped to undermine the centrality of projects for producing vaccines by means of attenuation that characterized Pastorian medical science until the death of its founder in 1895, and thus contributed to a closer alignment between the French and German work in medical microbiology. ${ }^{9}$ This, however, is not the subject I want to treat here. The orientation I propose arises quite naturally if we compare the recruitment at the Pasteur Institute with that at Koch's Hygiene Institute in

\footnotetext{
${ }^{4}$ Emil Roux and Alexandre Yersin, 'Contribution à l'étude de la diphthérie', Annales de l'Institut Pasteur 1888, 2 (12): 629-61.

${ }_{6}^{5}$ Behring and Kitasato, op. cit., note 1 above.

${ }^{6}$ Ibid., and Emil Behring, 'Untersuchungen über das Zustandekommen der Diphtherie-Immunität bei Thieren', Deutsch. med. Wochenschr., 1890, 16 (50): $1145-8$

${ }^{7}$ Starting in 1871 , the Germans annexed Alsace, which while being a great blow to French national pride also constituted a significant motivation for the scientific work of first Pasteur and later Roux.

${ }^{8}$ For a detailed and yet reflective intellectual biography of Koch, see Christoph Gradmann, Krankheit im Labor: Robert Koch und die medizinische Bakteriologie, Göttingen, Wallstein, 2005. There are
}

a number of biographies of Pasteur that analyse his approach to microbiological research. The most challenging is Gerald L Geison, The private science of Louis Pasteur, Princeton University Press, 1995, but other detailed presentations include Patrice Debré, Louis Pasteur, Paris, Flammarion, 1994.

${ }^{9}$ Andrew Mendelsohn, Cultures of bacteriology: formation and transformation of a science in France and Germany, 1870-1914, $\mathrm{PhD}$ thesis, Princeton University, 1996, pp. 299-309. Here, Mendelsohn argues that Roux's use of solid media, combined with the skills brought to Paris from Germany by Yersin, contributed to a re-alignment starting in 1885 . Their research on the virulence of germs progressively adopted the use of antiseptics described in the present paper. See pp. 313-35. 


\section{Jonathan Simon}

Berlin. ${ }^{10}$ It is striking that, while nearly all the researchers in Berlin were army medical officers, few of the scientists at the Pasteur Institute had more than a distant connection to the armed services. Indeed, Emile Roux's dismissal from the French army, apparently for insubordination, illustrates the distance that the first generation of Pastorians put between themselves and the army. ${ }^{11}$ Rather than take this to be simply a pragmatic result of Koch's recruitment policy — having the army pay for qualified staff was a way of keeping within a limited budget - I want to explore how the military careers of these scientists might have influenced their research interests and approaches, using the particularly significant case of Emil Behring to illustrate my argument.

\section{Behring and Iodoform}

The first issue I will treat is, therefore, the place of military medicine in Behring's research. Here, I want to underline the importance of the chemical disinfectants that were widely used in medicine during the second half of the nineteenth century, and became of particular interest to the German army following the Franco-Prussian war. In brief, my argument is that a set of experiments and publications concerning a number of such disinfectants would provide Behring with the tools necessary for his work in Berlin that touched on different therapeutic areas and eventually-almost accidentally-gave rise to serotherapy. Indeed, we shall see that Behring's early entry into the field of disinfection was not only important for his career as a military doctor, but also influenced his long-term scientific trajectory on two levels, providing two kinds of toolbox as it were. First, the chemical disinfectants themselves supplied Behring with a collection of physical research tools that he handled with skill in a widening range of applications. Second, the theoretical background that conceived practically all medical treatment of infectious disease in terms of disinfection provided the means for thinking about his research into possible cures for diphtheria and tetanus among other infectious diseases. Indeed, having made his discovery of the curative power of the blood of an immune animal, Behring consciously chose to consider the resulting serotherapy precisely in terms of this tradition of disinfection. What was exceptional about this case, however, was that the disinfectant was not a chemical agent, but the blood itself.

Thus, with respect to the therapeutic action of blood taken from other immunized animals, it is of little importance whether it has a direct influence on the bacteria or disables the pathogenic power of the bacteria's metabolic product.

I believe that I have the right to call both of these alternatives disinfection of the living organism. ${ }^{12}$

In order to draw out the significance of this thread of disinfection-thinking in Behring's work, I will follow his research from his first publications on iodoform in 1882 to the

\footnotetext{
${ }^{10}$ For a comparison of the structure and functioning of Koch's Institute for Hygiene and the Pasteur Institute, see Paul Weindling, 'Scientific elites and laboratory organisation in fin de siècle Paris and Berlin', in Andrew Cunningham and Perry Williams (eds), The laboratory revolution in medicine, Cambridge University Press, 1992, pp. 170-88.
}

\footnotetext{
${ }^{11}$ For this story about Roux, see Mary Cressac, Le Docteur Roux mon oncle, Paris, L'Arche, 1950. While others, like Edmond Nocard, may have volunteered to serve during the Franco-Prussian war, there were no military career doctors working for the Pasteur Institute at this time.

12 "Es kommt dabei wenig darauf an, ob wir bei den letztgenannten Heilwirkungen, die mit dem Blut
} 


\section{Emil Behring's Medical Culture}

development of the serotherapy less than a decade later. While doing this, I also aim to situate the chemical disinfectants involved in the industrial and military context of imperial Germany in the second half of the nineteenth century.

\section{The Early Publications of an Unknown Military Doctor}

Emil Behring's career path was quite typical of the scientists who staffed Koch's research institute at the end of the nineteenth century. Like many other research-oriented doctors who had received a free medical education courtesy of the army and then struggled to escape from the unpredictable nature of military postings around Prussia, Behring found a way out of the constraints of a typical military career through his scientific medical publications. Nevertheless, he knew that it was not by publishing case histories of diseases or their standard treatments that he would attract the attention of his fellow "scientific" doctors.

Behring opened his publication career while posted at Posen, ${ }^{13}$ an eastern outpost of the Prussian empire, with a series of three articles on the organic chemical compound and disinfectant, iodoform, all published in the Deutsche Medicinische Wochenschrift in 1882. The first, entitled 'Ueber Jodoform und Jodoformwirkung' (On Iodoform and its Effects), concerned the chemical and physical characteristics of the compound, as well as its reactions with a range of organic and inorganic reagents. The second article, 'Ueber Jodoformintoxication' (On Iodoform Poisoning), was more clinical in its approach and presented the various cases of poisoning associated with the use of this compound, while the third, 'Die Bedeutung des Jodoforms in der antiseptischen Wundbehandlung' (The Significance of Iodoform in the Antiseptic Dressing of Wounds), offered an overview of the place and functioning of iodoform in the practice of disinfection. These three articles reveal how Behring was seeking to situate himself as a chemistry-oriented medical researcher while still a junior medical officer in the Prussian army, and I will have more to say about them in what follows. From a professional perspective, however, while it would be an overstatement to claim that these articles made his reputation, they nevertheless attracted enough attention to start Behring on his way up and out of the standard career as a military doctor to which he was otherwise destined. The authoritative tone of the third paper in particular makes it clear that Behring was positioning himself as an arbiter in any debate concerning the effectiveness or toxicity of this particular chemical disinfectant.

These three publications from 1882 did not, however, represent Behring's first reflections on disinfectants. He had already put the elements of his own theory of disinfection down on paper in the form of notes that date from the end of $1881 .{ }^{14}$ Here, he summarized three possible ways of avoiding putrefaction that reflect the three pre-conditions for the occurrence of the phenomenon in the first place. First, one could try to make the nutritive material that nourished the germs responsible for corruption unsuitable in some way. Second, one could attempt to banish the germs responsible for the corruption, or third, render these germs non-functional. Behring's initial approach that underpinned his first

immunisirter anderer Thiere erzielt werden können, die Bacterien direkt beeinflussen, oder ob wir die krankmachenden Wirkungen ihrer Stoffwechselproducte paralysiren. Ich glaube ein Recht zu haben, beides als eine Desinfection im lebenden Organismus zu bezeichnen." Emil Behring, 'Ueber Desinfection am

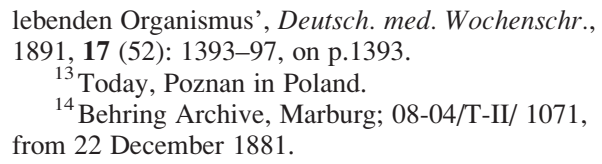
from 22 December 1881. 


\section{Jonathan Simon}

three publications would focus on the first line of attack-making the nutritive material unreceptive to putrefaction-famously taking smoked ham as his model of a medium rendered resistant to germs by a physical intervention. It is important to note that this was the only one of the three options that did not require dealing directly with the germs responsible for the putrefaction, and so lent itself more obviously to a chemical line of approach. Thus, while Behring was fully conscious of the role played by living microorganisms in the phenomenon of putrefaction, his approach to disinfection would not be in the style of Joseph Lister's anti-bacterial methods, where the immediate goal was to eradicate the germs responsible for infection. What first attracted Behring's attention was instead the chemical action of disinfectants - particularly iodoform-on liquid or solid bodily matter - the medium for infection — and not their purported bactericidal properties. With the benefit of hindsight, it is easy to make much of Behring's emphasis on the environment of the human body as a potential ally in the fight against infectious agents, but I believe it is more important to concentrate on his interest in novel disinfectants. It was in this context that he sought to distinguish himself as a young researcher by presenting an intriguing (if not wholly convincing) interpretation of the action of one such disinfectant.

Indeed, it is in this spirit that Behring offered his first publication on iodoform. ${ }^{15}$ Here, as I have already said, he described the chemical constitution and principal reactions of the compound. The specific goal of this first article was to identify which reagents were capable of releasing iodine from iodoform in a manner similar to heating the compound. The use of classic reagents such as mineral acids and alkalis was, however, only a prelude to the investigation that really mattered; the interaction between iodoform and the fluids and solids found in living bodies. The use of the compound by surgeons depended on its action at the sites of infection (composed of living matter, however damaged it may have been) where its disinfectant properties were to be understood and verified. The assumption underlying this approach was that iodoform was essentially an efficient means for delivering iodine to the site of infection. It was considered unnecessary to provide any further empirical proof of iodoform's efficacy, as the use of iodine as a disinfectant had already been empirically well established. In the end, these rather unrevealing laboratory experiments, which seemed to suggest that few such bodily products were capable of generating iodine from iodoform, allowed Behring to formulate an ambitious novel hypothesis to explain the peculiar virtue of iodoform in the treatment of wounds.

The inner working of the septic substances should be explained in the following way. Putrefaction, like any other process of decomposition of a living thing, generates or makes available oxidizing chemical bodies that generate iodine out of iodoform, as can be verified by microscopic observation. This freshly generated iodine is demonstrably capable of rendering those substances able to generate putrefaction [fäulnissfähige Substanzen] incapable of doing so and thus stops putrefaction in substances otherwise prone to it. ${ }^{16}$

Thus, while iodine was the disinfectant material of reference, according to Behring, iodoform generated a particularly powerful form of iodine that would stop putrefaction by rendering the usually fertile terrain of traumatized living matter unsuitable. We can

\footnotetext{
${ }^{15}$ Emil Behring, 'Ueber Jodoform und Jodoformwirkung', Deutsch. med. Wochenschr., 1882, 8 (11): 146-8.
}

16 “Die Einwirkung auf septische Substansten ist in folgender Weise zu erklären. Bei der Fäulniss wie bei allen lebhaften Zersetzungsprocessen enstehen oder 
interpret this model as the outcome of his decision a year previously to pursue the "smoked ham" model of disinfection, as there is no obvious chemical reason for Behring to think that any special form of iodine should be produced under these circumstances.

Behring's second article represents a turn away from this chemical approach, as here he addresses the clinical problem of poisoning associated with the compound. ${ }^{17}$ In it, Behring reports a collection of classic clinical cases of iodoform poisoning and the better-known syndrome caused by its more widely used counterpart, iodine poisoning. He uses this information as the basis for his opinion on the appropriate use of the compound, warning his readers against the internal use of iodoform. The construction of this article around this series of reports of clinical cases makes it a much more typical article for its time, as Behring completely dispenses with the chemical analyses less familiar to most practising doctors. Nevertheless, he comes back to chemistry in his conclusion, where he describes the effect of iodoform on the nervous system as being similar to the effects of chloroform poisoning. This is an opportunity to remind the reader of the similarity between the chemical structures of these two organic compounds.

The final article in this initial series offers an overview of the current knowledge and use of iodoform. ${ }^{18}$ Behring takes a more authoritative tone than in the two preceding articles, arguing that surgeons' rejection of iodoform is not justified by iodine poisoning (Jodismus), which is associated only with its internal use. Thus, while he re-affirms his opinion that iodoform should not be used internally for the treatment of venereal disease or cysts, he nevertheless defends the continued use of the chemical as an effective disinfectant. The tone of Behring's conclusion that closed this hat trick of publications for 1882 suggests he was by now if not the expert, at the very least a figure who had to be taken into account in any further discussion on the topic.

\section{The Medical Uses of Iodoform}

Why did Behring choose to publish on iodoform, and why did this substance merit such detailed investigation? Addressing these two questions leads us to a consideration of the special significance of disinfectants in imperial Germany, in particular in relation to military medicine in the wake of unification and the Franco-Prussian war of 1870-71.

Behring's orientation towards this substance was undoubtedly a career decision, as he must have been fully aware that iodoform was a controversial but fashionable topic for both clinical and physiological research, and the interest surrounding this relatively new disinfectant would facilitate his first venture into print. Not only would it be easier to get these first texts published, it would also be easier to get them noticed. As the Viennese surgeon, Johannes Mikulicz (1850-1905) remarked at the beginning of 1882, "In the last few months, the surgical literature has contained a whole range of useful articles on the use

sind vorhanden oxydirende chemische Körper, die, wie man sich durch mikroskopische Betrachtung überzeugen kann, aus Jodoform Jod entwickeln; das Jod in statu nascendi ist aber nachweislich im Stande, fäulnissfähige Substanzen in fäulnissunfähige zu verwandeln und in faulenden Substanzen die Fäulniss zu sistiren." Ibid., p. 147.

\footnotetext{
${ }^{17}$ Emil Behring, 'Ueber Jodoformintoxication', Deutsch. med. Wochenschr., 1882, 8 (20): 278-9, and 8 (21): 297-298.

${ }^{18}$ Emil Behring, 'Die Bedeutung des Jodoforms in der antiseptischen Wundbehandlung', Deutsch. med. Wochenschr., 1882, 8 (23): 321-3, and 1882, 8 (24): 336-337.
} 


\section{Jonathan Simon}

of iodoform." ${ }^{19}$ Indeed, in the Centralblatt für Chirurgie for that year, there were thirty-four entries concerning iodoform (including both original articles and reviews), compared with only two on its more traditional counterpart, iodine. Why was there such an intense interest in this compound? Iodoform was a product of chemical synthesis that started life in the laboratory of a French pharmacist and chemist, Georges Sérullas (1774-1832), in 1822. ${ }^{20}$ According to a review that appeared in Schmidt's Jahrbuch for 1864, the compound was subsequently introduced into medical practice by Dr Buchardat, based on the fact that it contained 90 per cent iodine by weight. ${ }^{21}$ As I have already suggested, the reasoning that justified the clinical application of this new organic chemical was that it was essentially a concentrated form of iodine, and would therefore possess disinfecting powers similar to, if not better than, this more venerable elementary disinfectant. This innovation in disinfection, like many others at the time, was received enthusiastically in certain medical circles, and doctors soon started experimenting with a wide range of external and internal applications. For some time, iodine salts, such as potassium iodide, had been given internally for the treatment of syphilis, so it is unsurprising that the internal applications for iodoform should focus on venereal disease. The most obvious use, however, was the external application to disinfect superficial wounds, and in this context, iodoform was seen as simply a more practical way of applying iodine. Interestingly, doctors also developed treatments that lay somewhere between external disinfection and introduction into the bloodstream through ingestion. Thus, in 1880, for example, W Watson Cheyne (1852-1932) published an article on the use of a bougie made out of cocoa butter, eucalyptus oil and iodoform that was to be inserted into the urethra as a treatment for blennorrhoea, recalling the longstanding function of iodides in the handling of venereal disease. ${ }^{22}$ Beyond these direct medical uses, however, the relative ease of manipulating iodoform permitted technical innovations in disinfection. In 1873, for example, a Leipzig journal promoted the use of iodoform paper instead of iodine for eliminating bad odours.

While the focus for internal use in German medicine was venereal disease, the applications suggested elsewhere were wide-ranging. In a review of Righini's early treatise on iodoform published in 1864, Kurzwelly presents a long list of diseases in which the product could be usefully applied including tuberculosis, scrofula, menstrual problems, tumours, retention of liquid in the uterus and breasts, male impotence, and more. ${ }^{23}$ The same review provided an equally wide range of modes for administering the medicine including the use of "iodoform cigarettes" that mixed iodoform with belladonna for the treatment of tuberculosis, asthma, laryngitis and chronic pharyngitis by inhalation of the smoke. ${ }^{24}$

Despite this range of applications, the principle interest for the military use of iodoform, and the one that Behring ended up stressing in his early publications, was the art of Wundbehandlung or the dressing of wounds, particularly gunshot wounds. Iodine had established its place in this area early in the nineteenth century, and by the time Behring

\footnotetext{
${ }^{19}$ J Mikulicz, 'Zur Jodoformbehandlung', Centralblatt für Chirurgie, 1882, p. 1.

${ }^{20}$ Iodoform $-\mathrm{CHI}_{3}-$ is the homologue of chloroform $-\mathrm{CHCl}_{3}$ - with the chlorine replaced by iodine.

${ }^{21}$ Kurzwelly, 'Das Jodoform. Eine Monographie mit Rücksicht auf Chemie, Physiologie, Pharmacie und Therapie, von Dr. J. Righini; aus dem Italienischen
}

übertragen von Dr E. Janssens', Schmidt's Jahrbücher der in- und ausländischen gesammten Medicin, 1864, 121: $25-31$.

${ }^{22} \mathrm{~W}$ Watson Cheyne, 'On a new method of arresting gonorrhoea', Br. med.J., 24 July 1880, ii: $124-5$.

${ }^{23}$ Kurzwelly, op. cit., note 21 above, p. 29.

${ }^{24}$ Ibid., p. 31. 


\section{Emil Behring's Medical Culture}

started his research on iodoform, it was used widely as a disinfectant. Indeed, one of the areas where this new chemical would find an enduring application was in iodoform dressings that could be applied directly to open wounds or the site of amputations, and could thus replace the standard combination of iodine and bandages. At the end of the nineteenth century, with Lister's technical innovation following on the microbial revolution of early pioneers like Pasteur, the role of disinfectants in medicine was changing. In the late 1860 s, Lister himself quite clearly distinguished his approach of antisepsis from the more traditional use of disinfectants in binding wounds:

In speaking of the antiseptic system of treatment, I refer to the systematic employment of some antiseptic substance, so as entirely to prevent the occurrence of putrefaction in the part concerned, as distinguished from the mere use of such an agent as a dressing. The latter has long been practised in many parts of the world. ${ }^{25}$

In the decade following the publication of his method, the reception of Lister's approach changed from scepticism to enthusiasm, and antiseptic techniques progressively won over surgeons, who could thereby reduce the rate of post-operational infection and death in their wards. From this perspective, alternative disinfectants like iodoform were of interest to a surgical community increasingly in favour of Listerian antisepsis. Furthermore, in terms of its physical characteristics - a water-insoluble solid at room temperature-this chemical formed a bridge between the traditional dressing of wounds with iodine and Lister's phenol-based approach of antisepsis, although carbolic acid was used as a topical disinfectant as well.

\section{Industry, Chemistry and Disinfection}

If we look at the origins of Lister's approach to antiseptis, we are inevitably confronted with the significance of the industrial revolution and urbanization in the genesis of this medical revolution. The carbolic (or phenolic) acid favoured by Joseph Lister (1827-1912) for his antiseptic system, like other coal-tar derivatives, was a by-product of the production of town gas that needed to be disposed of in one way or another. Thus, Lister recounts how he was originally inspired by the use of this product in a sewage treatment project in Carlisle.

In the course of the year 1864 I was much struck with an account of the remarkable effects produced by carbolic acid upon the sewage of the town of Carlisle, the admixture of a very small proportion not only preventing all odour from the lands irrigated with the refuse material, but, as it was stated, destroying the entozoa which usually infest cattle fed upon such pastures. ${ }^{26}$

Industrial logic naturally encouraged the use of this by-product of gas production for other ends. Nor should the coincidence between such poisonous by-products of modern urban technologies and the new microbial vision of disease and infection be passed over without comment. The technological and practical innovations of nineteenth-century biology that rendered bacterial agents visible under the microscope as well as allowing them to

\footnotetext{
${ }^{25}$ Joseph Lister, 'An address on the antiseptic system of treatment in surgery', Br. med. J., 18 July 1868, ii: pp. 53-6, on p. 53.
}

\footnotetext{
${ }^{26}$ Joseph Lister, 'On a new method of treating compound fracture, abscesses, \&c.', Lancet, 16 March 1867, i: 326.
} 


\section{Jonathan Simon}

be collected, stored, and cultivated under laboratory conditions were of the same order as those that drew unprecedented populations into towns seeking employment in factories. The rise of analytic and synthetic organic chemistry was likewise increasingly integrated into the process of industrialization, with interest in artificial dyes dependent on the massmanufacture of textiles in Britain and elsewhere. It was William Perkin's (1838-1907) discovery of mauve in 1856 that inaugurated the introduction of a range of phenol-based dyes, a crucial area of industrial research and development that came to be dominated by German chemical companies by the late nineteenth century. Thus, synthetic organic chemistry not only freed the textile industry from its dependence on costly plant-based dyes, but also supplied researchers with a host of new potential disinfectants to investigate. ${ }^{27}$ Although the synthesis of iodoform belonged to an earlier age of organic chemistry than the artificial dyestuffs, its integration into medical use was contemporary. It is not, therefore, surprising that a similar aura should surround iodoform as surrounded synthetic dyestuffs, as they were both seen as modern products of the chemistry laboratory, and symbolic of the science-based industrial power of a unified Germany. As is illustrated by the concerns around iodoform poisoning, however, these chemicals were not regarded as an unmitigated good. ${ }^{28}$

\section{War and Empire}

Besides its chemical industry, another symbol of the power of imperial Germany was the defeat of France, its former imperial neighbour and traditional enemy, in 1870. The entry of Prussian troops into Paris, and the ceding of Alsace-Lorraine to Germany were experienced by the French as stinging humiliations, but at the same time were seen by the Germans as a great victory of the newly unified nation. The Franco-Prussian war not only mobilized large armies for modern warfare, but also brought with it a re-examination of many aspects of military life, and military medicine was a prominent target for reform. Modern military medicine was to be brought closer to the front to deal quickly with the large number of wounds inflicted by increasingly effective artillery and more powerful small arms. The response that had generalized since the Napoleonic wars over half a century earlier was the mobile military hospital that could follow the army in its campaign and provide treatment for soldiers relatively near the front line, soon after they had received their injuries. The principal task of such a hospital was dressing the gunshot wounds of soldiers transported from the front, and the indispensable tools for this task were bandages and iodine.

The potential importance of iodoform bandages for the Prussian military was evident, as they constituted an effective means of combining disinfectant with bindings in a stable, readily available form. The unification of Germany and the build-up of the imperial army also encouraged the founding of new journals as well as other publications that specifically addressed military medical issues. An example of this development is the Deutsche Militärärztliche Zeitschrift ${ }^{29}$ that first appeared in 1872, and, although dominated by

\footnotetext{
${ }^{27}$ Anthony S Travis, The rainbow makers: the origins of the synthetic dyestuffs industry in western Europe, Bethlehem, Lehigh University Press, 1993.

${ }^{28}$ For more on industrial chemical pollution during this period, see the relevant contributions in Ernst Homburg, Anthony S Travis, and
}

\author{
Harm G Schröter (eds), The chemical industry \\ in Europe, 1850-1914: industrial growth, \\ pollution and professionalization, Berlin, \\ Springer, 1998. \\ ${ }^{29}$ The Deutsche Militärärtzliche Zeitschrift was \\ published between 1872 and 1912. The early issues
}


administrative and regulatory announcements, contained a number of articles concerning the use of disinfectants for cleansing wounds, as well as various antiseptic techniques and materials for use in surgery and elsewhere. In 1875, for example, an article presented the merits of carbolic and benzoic acids as disinfectants and preservatives for food, and 1877 saw the publication of investigations into the use of potassium chromate and hydrogen chloride as well as coal tar-the residue from burning coal to produce gas - as disinfectants for use in dressing wounds. Thus, Behring's publications in 1882 formed part of this wave of interest in the military applications of new chemical disinfectants, in tune with the idea that the application of modern chemicals could improve the emergency treatment of gunshot wounds in particular. Beyond providing a receptive audience for investigations into new disinfectants suited to modern military medicine, however, the German army also played a crucial administrative role in Behring's scientific career following his initial publications on iodoform.

\section{Carl Binz, Disinfectants, and Cadaverine}

In 1883 , Behring left Posen to take up a position at Winzig, ${ }^{30}$ where, in 1884 , he published an article on the subject of iodoform poisoning. ${ }^{31}$ Two years later, he was transferred to Bojanowo; a smaller town, although somewhat closer to his earlier posting in Posen. ${ }^{32}$ During April and May of 1886, however, Behring was given leave to take a bacteriology course with August Falk in Wiesbaden on the other side of Prussia, near the Rhine. ${ }^{33}$ The following year, Behring would receive an official appointment in the Rhine valley, with a change in affiliation taking him to the Institute for Pharmacology in Bonn. It is quite logical that his series of publications on iodoform from 1882 should lead Behring to Carl Binz (1832-1913), the director of the Institute for Pharmacology. A senior military doctor, and specialist in the physiological and chemical investigation of disinfectants, few were better placed than Binz to oversee the continuing experimental education of Behring in this field. Thus, in 1887, once he had qualified as a "Stabsarzt", Behring was transferred from Bojanowo to the Institute at Bonn. This move, like his subsequent departure from Bonn to join Koch's research group in Berlin in 1889, was a military administrative decision, but one certainly aimed at giving institutional recognition for Behring's early publications on iodoform and providing him with the possibility of building up this area of expertise. This transfer also definitively took Behring out of a potentially unending cycle of provincial postings in eastern Prussia, marking his promotion to a new level of research activity. ${ }^{34}$

Indeed, Binz was one of a number of German medical researchers who were interested in examining the growing range of disinfectants generated by German industrial organic

were edited by Dr Leuthold, Oberstabarzt at the Invalidenhause in Berlin.

${ }^{30}$ Although in Silesia, Winzig - now part of Poland and known as Wińsko — was a few hundred kilometres south of Posen.

${ }^{31}$ Emil Behring, 'Ueber Jodoformvergiftung und ihre Behandlung', Deutsch. med. Wochenschr., 1884 , 10 (5): 68-70.

\footnotetext{
${ }^{32}$ A small town about 50 miles south of Posen, Bojanowo is today in Poland.

${ }^{33} \mathrm{H}$ Zeiss and R Bieling, Behring: Gestalt und Werk, Berlin, B Schultz, 1940, p. 39.

${ }^{34}$ The loss of the relevant Prussian military documents makes it impossible to confirm this hypothesis concerning the aims of the military command in this case.
} 


\section{Jonathan Simon}

chemistry, and the scientists under him at the Institute for Pharmacology in Bonn were deploying an improving arsenal of analytic organic and pharmacological techniques to understand the nature and action of these chemicals. In his own publication on iodoform from 1878, Binz noted that while much was known about the use of the compound as a superficial disinfectant, relatively little experimentation had been performed to elucidate its internal action. As he pithily summed up the situation "little certain is known about the inner working of iodoform". 35 Although others at Bonn had studied certain aspects of iodoform, Behring's work represented the most thorough and original contribution to knowledge about this particularly promising modern disinfectant, and so his transfer to Bonn must have appeared quite natural. ${ }^{36}$

Upon Behring's arrival at the Institute for Pharmacology, Binz encouraged him to orient his studies more toward bacteriology, following up the initiative of the course he had taken in 1886. The move to Bonn had another dimension that is particularly relevant for the present argument, as it signalled Behring's immersion in a wider world of disinfectants than he had hitherto known. From a notebook that he started in Bonn in 1887, it seems that it was only here that Behring applied himself to gaining a thorough knowledge of organic chemistry. ${ }^{37}$ After this course in chemistry, he continued to make notes on recent work in synthetic organic chemistry, paying particular attention to the new synthetic colorants being produced by German industrial scientists. As I have already suggested, these colorants were not only of interest to microbiologists for dyeing their specimens, but also provided a source of potential new disinfectants. Behring's continued interest in disinfectants coupled with a growing expertise in bacteriology is confirmed by his contributions to scientific journals while in Bonn. In 1887, he published an article on the action of silver solution on the anthrax bacterium, ${ }^{38}$ and the following year, articles on the disinfectant and antiseptic properties of mercury chloride, an acetic acid complex formed with mercury chloride (Weinsäuresublimat), and creolin (another phenolic coal-tar product). These papers do not pursue the "smoked ham" model of disinfection applied to the action of iodoform, but are more "classic" analyses of these disinfectants in terms of their bactericidal properties. Two other papers appeared in the Deutsche Medicinische Wochenschrift of 1888 , however, that took Behring back to reconsider his theory of the anti-putrefying action of iodoform. First, in June, he published a paper on the possible role of cadaverine in the symptomology of cholera. Following up other research that showed that this organic compound $^{39}$ was generated by certain bacteria, Behring's first goal was to prove that cadaverine was itself toxic. He did this by means of experiments on a variety of animals, particularly guinea-pigs. He then argued by analogy from the associated symptoms and post-mortem observations that cadaverine could be responsible for at least some of the

\footnotetext{
35 "Wenig Sicheres ist von der innern Wirkung des Jodoform bekannt." Carl Binz, 'Ueber Jodoform und über Jodsäure', Archiv für experimentelle Pathologie und Pharmakologie, 1878, 8: 309.

${ }^{36}$ In 1877, Carl Möller defended a dissertation at the Rheinischen Friedrich-Wilhelms-Universität in Bonn, half of which was dedicated to iodoform. Carl Möller, Pharmakologische Untersuchungen über Jodoform und Jodsäure, MD thesis, Rheinischen FriedrichWilhelms-Universität, 1877.
}

\footnotetext{
${ }^{37}$ Behring Archive, Marburg, 08-04/T-II/1083.

${ }^{38}$ Emil Behring, 'Der antiseptische Wert der Silberlösungen und Behandlung von Milzbrand mit Silberlösungen', Deutsch. med. Wochenschr., 1887, 13 (37, 38): 805-7, 830-4.

${ }^{39}$ Pentamethylendiamine, or 1,5-diaminopentane had become increasingly identified with the chemical principle thought to be responsible for the putrefaction of dead bodies, cadaverine.
} 


\section{Emil Behring's Medical Culture}

symptoms associated with cholera. This interest in cadaverine and its toxic effects received a new twist two months later when Behring published an article on the relationship between this compound and iodoform. Here, he elucidated a chemical mechanism by which iodoform could neutralize the cadaverine that he had already identified as a poisonous product of certain pathogenic bacteria. He proposed that the three iodine atoms of each iodoform molecule $\left(\mathrm{CHI}_{3}\right)$ would be replaced by three cadaverine molecules $\left.(\mathrm{CH} \text { (cadaverine })_{3}\right)$ to give a harmless product. This evidently shows a shift in Behring's thinking away from his original model of the disinfective power of iodine in which he by-passed the role of bacteria by postulating that the iodoform rendered organic matter unfit for the micro-organisms responsible for putrefaction. In this new model, the bacteria are rendered harmless by neutralizing their toxic products; a vision that justifies Behring's conclusion that iodoform should qualify neither as an antiseptic nor as a disinfectant in the currently accepted sense of the terms - that they kill bacteria-because this was not its mechanism of action. Thus, despite a new, clearly signalled orientation towards microbiology, Behring retained his own particular understanding of iodoform as a "disinfectant", continuing to conceive it as a neutralizing chemical reagent rather than as a bactericide. Furthermore, the time spent in Bonn seems to have given Behring the chemical knowledge to propose a more plausible mechanism (in chemical terms at least) for this action.

The article on cadaverine and iodoform not only reveals this shift in Behring's thinking about the chemical action of iodoform, it also brings to light his widening circle of both scientific and institutional collaborators. Thus, Behring introduces the reader to a network of researchers grouped around both the supply of cadaverine and ongoing physiological experimentation. The first, Ernst von Scheurlen (1863-1897), was Behring's long-time friend and collaborator, but there were others such as de Ruyter and Julius Petri (18521921 ) in Berlin, and Albert Ladenburg (1842-1911) in Bonn. Furthermore, a need for raw materials for this research brought Behring into contact with Emanuel Merck (1855-1923), a prominent member of the successful entrepreneurial Merck family, whose wholesale laboratory in Darmstadt was able to supply pure cadaverine. Behring also had contact with students working on disinfectants in Bonn. In April 1889, for example, Oscar Kniffler defended his dissertation on 'The Inner Application of Iodoform' at the Medical faculty, in which he cited a number of experiments that Behring was carrying out at the time. At the end, Kniffler of course thanked Binz as director of the project, but he also explicitly acknowledged Behring for "his friendly support" and his willingness to discuss the student's work. ${ }^{40}$ Nevertheless, despite the significance and relevance of the research being carried out at Bonn, the focus for scientific ambition under the German empire remained at its capital city, Berlin. ${ }^{41}$

\section{Koch's Institute, Serum, and other Disinfectants}

The move to Koch's Hygiene Institute in Berlin coincided with the highpoint of Behring's scientific research, as it was in Berlin that he would make the breakthroughs leading to serum therapy first for diphtheria, and later for tetanus. This discovery brought him

\footnotetext{
${ }^{40}$ Oscar Kniffler, Jodoform zur inneren Anwendung, MD thesis, Rheinische FriedrichWilhelms-Universität, 1889 , p. 33.
} 


\section{Jonathan Simon}

international recognition in the form of a Nobel Prize, the enduring status of a hero in German history of medicine, as well as his own successful business producing serum. It was also as a researcher at the Hygiene Institute in Berlin that Behring would present himself as the new expert on disinfectants, and a potential successor to Koch. Thus, in 1890 , the same year in which he made public the fruits of his collaborative research with Kitasato on the curative powers of serum, Behring also published a review of disinfectants under his own name. ${ }^{42}$ Unlike the research on serum, this latter article appeared in Koch's journal, the Zeitschrift für Hygiene, and, over the course of eighty pages, Behring discussed a wide range of disinfectants with which he was now familiar, and which would play a crucial role in the practical development of serum therapy. ${ }^{43}$ The disinfectants were divided into eight sections, with the first six defined according to the physico-chemical nature of the agents: metal salts, acids and alkalis, organic compounds based on the aromatic ring (phenols), liquid disinfectants insoluble or slightly soluble in water, insoluble solid substances, and gaseous substances. Thus, iodoform falls into the fifth category of the insoluble solid disinfectants, where it is joined principally by preparations derived from mercury, gold and other heavy metals. Behring maintains his eccentric position that, unlike the other chemicals he discusses, iodoform is not a bactericide but instead works by acting on the environment to undermine the bacteria's capacity to survive. The reaction between cadaverine and iodoform published two years earlier does not, however, make it into this review of disinfectants.

I do not intend to go through all the chemical disinfectants that Behring discussed under these six headings cited above, but will consider only iodine trichloride, a double halogen compound that would supply the initial technical means adopted by Behring and Erich Wernicke (1859-1928) to immunize large animals (initially sheep, and ultimately horses) against diphtheria. Thus, it was the use of this particular disinfectant that provided the key to the initial production of serum for the treatment of diphtheria. My selective treatment of iodine trichloride is, however, to save space rather than for any more principled reason. Indeed, the point I want to underline here is that the use of this agent followed a programme of research that screened a wide variety of chemicals in the context of investigations that also experimented with a range of therapeutic strategies. Thus, the identification of the technique using iodine trichloride and the subsequent development of serum therapy was an empirical outcome of this wide-ranging approach rather than being a deliberately planned use of the chemical based on any theoretical principles.

For Behring, iodine trichloride is a more typical disinfectant than iodoform, as it has direct anti-bacterial properties that are observable in vitro, using colonies of pathogenic micro-organisms cultured on a suitable medium. Following a series of tests that compared carbolic acid, mercury sublimate (chloride) and iodine trichloride in terms of their capacity to kill anthrax bacilli, and their toxicity in rabbits, iodine trichloride was singled out as having the most favourable ratio of disinfectant power to toxicity. Behring also took the opportunity of this article to announce the therapeutic success he had obtained by injecting

\footnotetext{
${ }^{42}$ It is interesting to note that in January 1890 , Behring was taking a course in hygiene at the Robert Koch Institute, in which Oscar Boer taught a section on the action of disinfectants on bacteria, 08-04/T-II/1086,
}

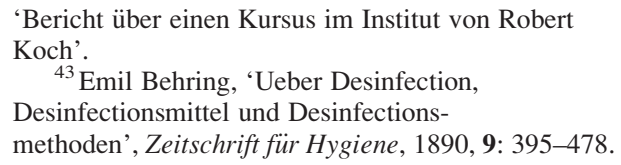


iodine trichloride into the site of an earlier injection of a virulent diphtheria culture. The fact that the disinfectant was being used to eliminate the pathogen inside the animal's body is significant, but not extraordinary, and certainly cannot be straightforwardly read as a conceptual precursor for Behring's serotherapy. This kind of "inner disinfection" technique, involving the internal administration of disinfectants to cure microbial infections, had also been used, for example, by Georg Cornet in the context of the search for a treatment for tuberculosis. Nevertheless, it is important to remember that this type of inner disinfection technique was just one out of many used by German researchers in the 1880s in an effort to develop therapeutic applications in the realm of medical microbiology, as will be discussed in more detail below. Furthermore, while Behring judged iodine trichloride to be the most effective agent in this context, it was not the only disinfectant to impress him during the course of these studies.

Iodine trichloride is not the only compound with which one can obtain good therapeutic results on guinea-pigs with diphtheria. Others such as naphthylamine, and gold-sodium chloride among the metal salts, have proved effective. Nevertheless, up until now the best results have been achieved using iodine trichloride. ${ }^{44}$

Following his presentation of a large number of well-defined, relatively pure organic and inorganic chemicals, Behring introduced a new form of disinfectant that was of quite a different nature. Indeed, the last two types of disinfectant listed in Behring's review from 1890 were not defined in chemical terms at all but instead according to their origin and action; these were, first, chemical products from micro-organisms, and second, bactericides present in animals and humans, i.e. their blood. While he has little to say about the first of these, he stresses the radical novelty of the second. Thus, he not only characterizes blood sera as "disinfectants" but also claims that this discovery constitutes a new "chapter in disinfection theory". To understand this connection between serotherapy and disinfection, we need to look at the context of microbiological research in Berlin at this time, opening our perspective to include a group of experimental scientists who, like Behring himself, had gravitated towards Koch in Berlin.

\section{Berlin, Disinfection and Serotherapy}

The discovery by Kitasato and Behring that the blood of immune animals could be used as a treatment for experimental tetanus and diphtheria (in other animals) led to the search for reliable means to induce immunity in animals, with the aim of producing a serum that could eventually be used in human disease. It is only too easy to trace out this path from animal experiments to the human application of serotherapy once one is armed with the knowledge that this technique was destined to become an important element of the modern therapeutic arsenal. Nevertheless, in examining the research itself, we need to bear at least two things in mind. First, it was far from certain that this approach would succeed for a number of reasons. Not only was there a possibility that no operational means could be

\footnotetext{
44 “Das Jodtrichlorid ist nicht das einzige Mittel, mit welchem man gute Heilresultate bei der Diphtherie der Meerschweinchen erzielen kann ; auch

Naphthylamin und unter den Metallsalzen namentlich
}

das Goldnatriumchlorid erwiesen sich wirksam; indessen waren bis jetzt die Erfolge mit dem Jodtrichlorid die besten." Ibid., p. 464. 


\section{Jonathan Simon}

found to immunize animals, but it was also far from certain that a treatment that worked in rabbits would be effective for human beings. Second, this line of research was just one among many undertaken in the effort to find an effective treatment for infectious diseases such as diphtheria, tuberculosis and tetanus, following the relatively recent identification of a series of micro-organisms as responsible for the pathologies in question. Thus, both Kitasato and Behring's initial investigations and the subsequent experiments aimed at inducing immunity were conducted in the context of a considerable amount of related animal experimentation aimed at developing therapies for infectious diseases. While relatively few of these projects would result in applied, let alone effective therapies, the researchers were evidently not in a position to know this at the time. Furthermore, this microbiological research directed towards therapeutic applications itself took place in a context of vigorous competition both within and outside the Berlin research community. Even before the apparent success of Pasteur's treatment for rabies in the mid-1880s, the race was on to develop a successful therapy for a major disease such as diphtheria or tetanus (or the greatest prize of them all-tuberculosis), with the Pasteur Institute a powerful competitor of Berlin's Hygiene Institute. ${ }^{45}$ Nor was Behring alone in conducting this kind of research in Berlin, with Georg Cornet (1858-1915), Carl Fraenkel (1861-1915), Hans Aronson (1865-1919), Oscar Boer (1847-1897) and Robert Koch himself all engaged in animal experimentation that was meant to result more or less directly in therapeutic applications. In what can best be described as a loosely-integrated, wide-ranging research programme, these German medical scientists deployed a variety of techniques, running the gamut from the most "traditional" approach of attenuating the bacteria using heat or chemicals-pioneered by Pasteur-to the pre-treatment of experimental animals with disinfectants such as hydrogen peroxide, before infecting them with a pathogenic bacillus. On the one hand, some of these approaches-such as feeding animals with the toxin produced by a bacterium, to accustom their bodies to its effects-were far removed from any disinfection techniques. On the other, as I mentioned above, various forms of "inner disinfection" were considered promising approaches, with Behring and others attempting to cure infected animals by the internal administration of disinfectants both before and after infection. ${ }^{46}$ The concept of inner disinfection, however, itself covered quite a broad range of practices, accompanied by similarly diverse interpretations of its possible mode of action. Thus, in his 1889 article on the internal action of disinfectants on animals infected with tuberculosis, Cornet hypothesized that the "bathing" of the infected

\footnotetext{
${ }^{45}$ This competition around the diphtheria antitoxin is well analysed in Paul Weindling, 'From medical research to clinical practice: serum therapy for diphtheria in the 1890s', in John Pickstone (ed.), Medical innovations in historical perspective, New York, St Martin's Press, 1992, pp. 72-83. For more on the history of tuberculin as a treatment, see Christoph Gradmann, 'Redemption, danger and risk: the history of anti-bacterial chemotherapy and the transformation of tuberculin', in Thomas Schlich and Ulrich Tröhler (eds), The risks of medical innovation: risk perception and assessment in historical context, London, Routledge, 2005, pp. 53-70.
}

\footnotetext{
${ }^{46}$ The nine methods retained by Behring in his subsequent account of the period were the following: sterilizing the bacteria at high temperature, pretreating the culture with iodine trichloride, using the bodily fluids of sick animals to induce immunity in others, using chemical agents to cure infected animals, using hydrogen peroxide (a disinfectant) as a prophylactic, employing attenuated bacteria culture followed by a full strength one, using pre-treated toxin, trying incremental doses of toxin, and feeding the animals with the toxin. See Emil Behring, Die Geschichte der Diphtherie. Mit besondere Berücksichtigung der Immunitätslehre, Leipzig, Georg Thieme, 1893, p. 148.
} 


\section{Emil Behring's Medical Culture}

flesh in disinfectant could sterilize it and so stop the spread of the bacteria. ${ }^{47}$ By contrast, as we have already seen, Behring qualified the ability of blood to neutralize the toxins produced by bacteria in the same terms of disinfection.

It was in the context of this therapeutic disinfection research programme that Behring conducted a series of experiments in collaboration with Boer, involving the use of some thirty chemical agents to try and cure animals already infected with "experimental" diphtheria, ${ }^{48}$ which was a continuation of Behring's own longstanding attempts to treat anthrax in laboratory animals by the same means. In parallel to the continued pursuit of traditional disinfectants, Behring was also studying the disinfective power of blood. This research started with experiments on the bactericidal effects of rats' blood on anthrax bacilli while Behring was still in Bonn, but was pushed much further in collaboration with Franz Nissen, when Behring arrived in Berlin. Not all blood was the same in terms of its bactericidal effects, and, in particular, while blood from normal guinea-pigs had no effect against the Vibrio metschnikovi, blood from animals immunized against this bacterium could kill it in vitro. Although this result led Behring to recognize the specificity (and unpredictability!) of blood's antibacterial properties, and even prompted him to speculate about the possibly non-chemical origin of these properties, this work is still much closer to the disinfectant tradition than any alternative explanation of immunity, as he continued to think of blood as containing a collection of disinfectants.

Finally, Behring's work with Kitasato on the transfer of immunity against diphtheria and tetanus using the animals' blood-serum followed on directly from this research on the antiseptic power of blood serum, with the serum's action conceptualized as a form of inner disinfection. The idea was that the specific bactericidal power of serum from immunized animals that had been observed in vitro acting against the Vibrio metschnikovi, was being applied internally.

The success of Behring and Kitasato's transfer of immunity, and the therapeutic vistas it opened up, lent Behring's more traditional range of disinfectants a different practical significance. If the injection of hydrogen peroxide, for example, could, by means of some form of internal disinfection, protect an animal against the lethal effects of diphtheria and thereby help to render it immune, then the technique could potentially serve to produce serum for treating other animals or even humans suffering from the disease. Thus, rather than taking the risk of injecting diphtheria patients with hydrogen peroxide directly, there now existed the apparently safer possibility of using the same procedure in animals in order to generate a serum for human administration. In the end, Behring's favoured technique for inducing immunity - the essential preliminary for extracting the therapeutic serum-was not any form of inner disinfection, however, but the pre-treatment of a diphtheria culture (and later the toxin) using iodine trichloride. This manipulation rendered the culture or toxin less deadly and thereby facilitated the process of immunization. Following this initial

\footnotetext{
${ }^{47}$ Georg Cornet, 'Ueber das Verhalten der Tuberkelbacillen im thierischen Organismus unter dem Einfluss entwickelungshemmender Stoffe', Zeitschrift für Hygiene, 1889, 5: 100-1, cited in Gradmann, op. cit., note 8 above, p. 138 .

${ }^{48}$ Oscar Boer, 'Ueber die Behandlung diphtherieinfizierter Meerschweinchen mit
}

chemischen Präparaten', Zeitschrift für Hygiene und Infektionskrankheiten, 1892, 11: 154-64. "Experimental" disease was the term used to describe human disease induced in an animal usually by the inoculation of a bacterial culture. 


\section{Jonathan Simon}

stage, Behring successively reduced the iodine trichloride concentration in subsequent injections of toxin, until the animal could eventually be exposed to untreated toxin, thereby completing the process of artificial immunization. This initial successful method developed for immunizing large animals was put in place following a painstaking trial and error investigation conducted by Wernicke in collaboration with Behring. ${ }^{49}$ The addition of iodine trichloride prior to injecting the culture was not a novel technique developed specifically in this context, however, but one of the range of disinfection techniques that were being explored by Boer and by Fraenkel as well as by Behring himself in the therapeutic disinfection research programme outlined above. Here, then in the initial elaboration of serotherapy for human use, we witness the practical utility of certain experimental disinfection techniques. These resulted from the experimental extension (to therapeutic applications in infectious disease) of the investigation of new potential disinfectants that were of capital importance to a (military) medical culture increasingly sensitive to issues of disinfection. In this light, it is no longer surprising that Behring conceived this new therapy in terms of disinfection, as this was the context out of which it arose. It is only after serotherapy has been located in the history of immunology, however, and the history of experimental therapeutic disinfection techniques has disappeared from sight, that Behring's research career loses its coherence and his interpretation of serotherapy as disinfection starts to sound so eccentric.

\section{Conclusion}

Behring's initial interest in iodoform seems to have been motivated as much by professional as by scientific concerns, and yet it introduced him into a world of disinfectants that would exercise a crucial influence over his subsequent medical research. This interest in disinfectants, although military in origin, was widely shared in the circle of Berlin scientists working on infectious disease at Koch's Institutes, including Koch himself. Thus, disinfectants played a triple role in Behring's research career, first, an introductory role as a therapeutic agent in military medicine that led him from "mundane" concerns of dressing wounds into an innovative area of therapeutic microbial research being conducted in Berlin. Second, disinfectants played an important material role in his research, as the wide range of substances (in particular organic chemicals synthesized in the context of the new dye industry) served as a rich resource for solving biological problems, such as how to develop a practical technique for immunizing different animals against microbial infectious disease. Last, but not least, at the theoretical level, the action of disinfectantsdisinfection or antisepsis-provided a model for thinking about many different types of therapy. Despite the fact that the conception of serotherapy as disinfection would rapidly become outmoded in the wake of more coherent and convincing theories of immunity, it was a key factor in developing this new therapy. Thus, I want to argue, the medical revolution of serotherapy owed much more to the wide-ranging programme of practical microbiological experimentation, which to a large extent turned around modern chemical disinfectants, than to any particular immunological theory.

\footnotetext{
${ }^{49}$ Erika Schulte, Der Anteil Erich Wernickes an der Entwicklung des Diphtherieantitoxins, MD thesis, Berlin, 2000.
} 